\title{
Hubungan Kejadian Pneumonia Neonatus dengan Beberapa Faktor Risiko di RSUP Dr. M. Djamil Padang Periode 2010- 2012
}

Rizki Meizikri ${ }^{1}$, Finny Fitry Yani $^{2}$, Yusrawati $^{3}$

\begin{abstract}
Abstrak
Pneumonia merupakan salah satu penyebab mortalitas utama pada neonatus. Bayi Berat Lahir Rendah (BBLR), kelahiran preterm, ketuban pecah dini (KPD), dan demam intrapartum merupakan faktor risiko yang dapat berpengaruh terhadap kejadian pneumonia neonatus. Tujuan penelitian ini adalah menentukan hubungan antara faktor risiko tersebut dengan kejadian pneumonia neonatus di RSUP M. Djamil. Penelitian ini bersifat analitik dengan desain cross-sectional dengan mengumpulkan data rekam medis pneumonia neonatus di RSUP M. Djamil Padang periode 2010 - 2012. Kontrol diambil data neonatus yang dirawat dengan diagnosis selain pneumonia pada periode yang sama. Neonatus dengan diagnosis sindrom gawat nafas, sepsis, meningitis, asfiksia, dan aspirasi telah dieksklusi terlebih dahulu. Sejumlah 49 sampel yang memenuhi kriteria terdapat temuan; KPD sebanyak 22,4\%, demam intrapartum 20,4\%, BBLR 18,4\%, dan kelahiran preterm 10,2\%. Sebanyak 24 sampel tidak memiliki faktor risiko. Analisis bivariat chi-square menunjukkan bahwa BBLR $(p=0,46)$, kelahiran preterm $(p=0,372), \operatorname{KPD}(p=0,616)$, dan demam intrapartum $(p=0,083)$ tidak memiliki hubungan yang signifikan dengan kejadian pneumonia neonatus di RSUP M. Djamil periode 2010-2012.
\end{abstract}

Kata kunci: pneumonia neonatus, BBLR, kelahiran preterm, KPD, demam intrapartum.

\begin{abstract}
Pneumonia is one of leading mortality causes among neonates. Low Birth Weight (LBW), preterm birth, Premature Rupture Of Membranes (PROM) and intrapartum maternal fever are known as risk factors that might contribute to neonatal pneumonia occurence. The objective of this study was to determine relationship the risk factors to neonatal pneumonia in M. Djamil hospital. This analytic research with cross-sectional design compiled neonatal pneumonia data from 2010-2012 medical record M. Djamil hospital. Controls were taken from neonates hospitalized in M. Djamil within the same period. Neonates with respiratory distress syndrome, sepsis, meningitis, asphyxia, and aspiration were excluded. The 49 subjects that meet research criteria, PROM were found in 22,4\% of neonates, intrapartum fever 20,4\%, LBW 18,4\%, and preterm birth 10,2\%. Twenty four of them do not have any of those risk factors. Bivariate analysis with chi-square shows that none of those risk factors are significantly related to neonatal pneumonia in M. Djamil hospital period 2010-2012 (LBW $p=0,46$; preterm birth $p=0,372$; PROM $p=0,616$; intrapartum fever $p=0,083$ ).
\end{abstract}

Keywords: neonatal pneumonia, LBW, preterm birth, PROM, intrapartum fever

Affiliasi penulis: 1. Prodi Profesi Dokter FK UNAND (Fakultas Kedokteran Universitas Andalas Padang), 2. Bagian Anak FK UNAND/RSUP Dr. M.Djamil Padang, 3. Bagian Obstetri Ginekologi/RSUP Dr. M.Djamil Padang.
Korespondensi: Rizki Meizikri,E-mail: rizkimz@gmail.com HP: 08982277652 


\section{PENDAHULUAN}

Bayi baru lahir (neonatus) merupakan masa yang paling rentan terinfeksi. Salah satu penyakit infeksi yang merupakan penyebab mortalitas utama pada neonatus adalah pneumonia. ${ }^{1,2}$

Ketika sistem imun seseorang dalam keadaan baik, kuman penyebab pneumonia dapat dihancurkan oleh makrofag alveolus. Kuman penyebab pneumonia dapat menginfeksi orang yang sistem pertahanan tubuhnya lemah atau belum kompeten, misalnya neonatus., Pneumonia pada neonatus dapat diakibatkan karena proses yang terjadi dalam kehamilan, ketika proses persalinan, maupun didapatkan setelah kelahiran. Berdasarkan onset kejadiannya, pneumonia neonatus intranatal termasuk ke dalan pneumonia awitan dini (early onset) dan pneumonia neonatus postnatal ke dalam pneumonia awitan lambat (late onset). ${ }^{1,3-5}$.

Kemungkinan terinfeksi pneumonia semakin tinggi jika terdapat faktor risiko yang mendukung, di antaranya berat lahir rendah, kelahiran preterm, demam intrapartum dan ketuban pecah dini (KPD). Beberapa penelitian menunjukkan bahwa berat lahir rendah dan kelahiran preterm merupakan faktor risiko yang signifikan terhadap kejadian pneumonia neonatus. Penelitian lain menunjukkan adanya hubungan linear terhadap peningkatan risiko infeksi pada neonatus. Peningkatan risiko infeksi terlihat pada suhu $37,5^{\circ} \mathrm{C}$ sampai $38^{\circ} \mathrm{C}$. Peningkatan ekstrim dari risiko infeksi pada neonatus diobservasi pada suhu lebih dari $38^{\circ} \mathrm{C}$. Pada suhu $39,16^{\circ} \mathrm{C}$ terdapat lonjakan kasus infeksi empat kali lipat dibandingkan dengan suhu $38,3^{\circ} \mathrm{C}^{4,6-9}$

Data rekam medis RSUP M. Djamil Padang menunjukkan bahwa terdapat 190 neonatus yang didiagnosis pneumonia dalam rentang 2010 sampai 2012, dengan rincian 24 kasus pada tahun 2010, 58 kasus pada 2011dan 108 kasus pada 2012.

\section{METODE}

Penelitian ini merupakan studi analitik dengan desain cross-sectional study. Populasi penelitian adalah seluruh neonatus yang dirawat di RSUP dr. M. Djamil periode 2010-2012. Sampel diambil dengan metode total sampling. Kriteria inklusi penelitian ini adalah bayi yang didiagnosis pneumonia pada usia kurang dari 28 hari. Kriteria eksklusi pada penelitian ini adalah bayi dengan data rekam medis yang tidak lengkap dan bayi yang pada diagnosis akhir dokter tidak terbukti pneumonia.

Variabel bebas adalah BBLR, kelahiran preterm, demam intrapartum, dan KPD. Variabel terikat pada penelitian adalah pneumonia neonatus.

Pengolahan data yang dilakukan adalah pengambilan data pneumonia neonatus dari bagian rekam medik RSUP Dr. M. Djamil. Data dipilah sesuai dengan kriteria inklusi dan eksklusi. Setelah itu, dilakukan pengambilan data kontrol dari populasi, yaitu neonatus yang dirawat di RSUP Dr. M. Djamil tahun 2010-2012. Neonatus yang dirawat dengan diagnosis banding pneumonia yaitu sepsis, meningitis, asfiksia, aspirasi dan sindrom gawat nafas tidak disertakan ke dalam kontrol. Data selanjutnya diolah secara komputerisasi dengan uji chi-square untuk mengetahui hubungan tiap faktor risiko yang diteliti dengan pneumonia neonatus.

\section{HASIL}

Berdasarkan Tabel 1, terdapat 190 neonatus di RSUP Dr. M. Djamil yang didiagnosis pneumonia dalam rentang 2010 sampai 2012, dengan rincian 24 kasus pada tahun 2010, 58 kasus pada 2011, dan 108 kasus pada 2012

Tabel 1. Distribusi jumlah subjek penelitian per tahun dan penolong persalinan

\begin{tabular}{ccccccc}
\hline \multirow{2}{*}{ Tahun } & \multirow{2}{*}{ Jumlah } & Presentase & \multicolumn{5}{l}{ Penolong Persalinan } \\
\cline { 4 - 7 } & & & M.Djamil & $\begin{array}{c}\text { RS } \\
\text { Lain }\end{array}$ & Bidan & $\begin{array}{c}\text { Lain- } \\
\text { Lain }\end{array}$ \\
\hline 2010 & 12 & $24.5 \%$ & 0 & 4 & 7 & 1 \\
2011 & 18 & $36.7 \%$ & 6 & 6 & 5 & 1 \\
2012 & 19 & $38.8 \%$ & 4 & 8 & 6 & 1 \\
Total & 49 & $100 \%$ & 10 & 18 & 18 & 3 \\
\hline
\end{tabular}

Sebanyak 69 neonatus memiliki diagnosis utama pneumonia, namun hanya 49 neonatus yang memenuhi kriteria untuk dijadikan subjek penelitian, dengan rincian 12 pasien tahun 2010, 18 pasien 2011, dan 19 pasien tahun 2012. 
Tabel 2. Distribusi berat badan dan usia subjek penelitian

\begin{tabular}{ccccccc}
\hline \multirow{2}{*}{ Tahun } & \multicolumn{3}{c}{ Berat Badan } & \multicolumn{3}{c}{ Usia } \\
\cline { 2 - 7 } & $<\mathbf{2 , 5}$ & $\mathbf{2 , 5 - 4}$ & $>\mathbf{4}$ & $\mathbf{0 - 1 0}$ & $\mathbf{1 1 - 2 0}$ & $\mathbf{2 1 - 2 8}$ \\
\hline 2010 & 1 & 9 & 2 & 9 & 2 & 1 \\
2011 & 4 & 13 & 1 & 18 & 0 & 0 \\
2012 & 4 & 15 & 0 & 19 & 0 & 0 \\
\hline Total & 9 & 37 & 3 & 46 & 2 & 1 \\
\hline
\end{tabular}

Tabel 2 menunjukkan bahwa sebagian besar subjek penelitian (37 pasien) memiliki berat badan lahir antara 2,5-4 kilogram (berat lahir cukup). Sembilan pasien merupakan pasien dengan faktor risiko berat lahir rendah dan tiga pasien memiliki berat badan lebih dari 4 kilogram. Sementara itu, mayoritas usia pasien berkisar antara 0-10 hari, yaitu sebanyak 46 pasien. Hanya 2 pasien yang berusia 11-20 hari, dan hanya 1 pasien yang berusia 21-28 hari. Sebanyak 38 dari 46 pasien berusia 0-10 hari tersebut mengalami pneumonia awitan dini (berusia kurang dari 2 hari).

Tabel 3. Presentase BBLR pada sampel dan control

\begin{tabular}{cccc}
\hline $\begin{array}{c}\text { Pneumonia } \\
\text { BBLR }\end{array}$ & Pneumonia & $\begin{array}{c}\text { Tidak } \\
\text { Pneumonia }\end{array}$ & $\begin{array}{c}\mathbf{p} \\
(<\mathbf{0}, \mathbf{0 5})\end{array}$ \\
\hline Ya & $9(18,4 \%)$ & $12(24,5 \%)$ & 0,460 \\
Tidak & $40(81,6 \%)$ & $37(75,5 \%)$ & \\
Total & $49(100 \%)$ & $49(100 \%)$ & \\
\hline
\end{tabular}

Data pada Tabel 3 menunjukkan bahwa sebanyak 9 dari 49 neonatus (18\%) adalah BBLR. Sementara itu, pada 49 neonatus kontrol, sebanyak 12 neonatus (24\%) merupakan BBLR. Secara statistik, tidak didapatkan hubungan yang signifikan antara BBLR dengan pneumonia neonatus $(p=0,460)$.

Tabel 4. Presentase kelahiran pretermpada sampel dan kontrol

\begin{tabular}{cccc}
\hline $\begin{array}{c}\text { Pneumonia } \\
\text { Preterm }\end{array}$ & Pneumonia & $\begin{array}{c}\text { Tidak } \\
\text { Pneumonia }\end{array}$ & $\begin{array}{c}\mathbf{p} \\
(<0,05)\end{array}$ \\
\hline Ya & $5(10,2 \%)$ & $8(16,3 \%)$ & 0,372 \\
Tidak & $44(90,8 \%)$ & $41(83,7 \%)$ & \\
Total & $49(100 \%)$ & $49(100 \%)$ & \\
\hline
\end{tabular}

Tabel 4 menunjukkan presentase kelahiran preterm pada sampel dan kontrol. Pada penelitian ini didapatkan 5 neonatus yang lahir preterm (10,2\%). Dari 49 neonatus kontrol ditemukan delapan neonatus preterm (16,3\%). Analisis statistik tidak menunjukkan hubungan yang signifikan antara kelahiran preterm dengan pneumonia neonatus ( $p=0,372)$.

Tabel 5. Presentase KPD pada sampel dan kontrol

\begin{tabular}{cccc}
\hline $\begin{array}{l}\text { Pneumonia } \\
\text { KPD }\end{array}$ & Pneumonia & $\begin{array}{c}\text { Tidak } \\
\text { Pneumonia }\end{array}$ & $\begin{array}{c}\mathbf{p} \\
(<\mathbf{0 , 0 5})\end{array}$ \\
\hline KPD & $11(22,4 \%)$ & $9(18,4 \%)$ & 0,616 \\
Tidak KPD & $38(77,6 \%)$ & $40(81,6 \%)$ & \\
Total & $49(100 \%)$ & $49(100 \%)$ & \\
\hline
\end{tabular}

Pada Tabel 5 dapat dilihat bahwa ditemukan 11 sampel dengan riwayat ibu KPD (22,4\%). Sementara itu, ditemukan sebanyak 9 kejadian KPD pada neonatus yang dijadikan kontrol. Walaupun pada penelitian ini KPD merupakan faktor risiko yang paling banyak ditemukan, analisis statistik tidak menunjukkan adanya hubungan yang signifikan antara KPD dengan pneumonia neonatus $(p=0,616)$.

Tabel 6. Presentase demam intrapartum pada sampel dan kontrol

\begin{tabular}{cccc}
\hline $\begin{array}{c}\text { Pneumonia } \\
\text { Demam }\end{array}$ & Pneumonia & $\begin{array}{c}\text { Tidak } \\
\text { Pneumonia }\end{array}$ & $\begin{array}{c}\mathbf{p} \\
(<\mathbf{0 , 0 5})\end{array}$ \\
\hline Ya & $10(20,4 \%)$ & $4(8,2 \%)$ & 0,083 \\
Tidak & $39(79,6 \%)$ & $45(91,8 \%)$ & \\
Total & $49(100 \%)$ & $49(100 \%)$ & \\
\hline
\end{tabular}

Berdasarkan data pada Tabel 6, demam intrapartum merupakan faktor risiko terbanyak kedua yang ditemukan pada sampel, yaitu sebanyak 10 kejadian (20,4\%). Pada neonatus yang dijadikan kontrol, ditemukan sebanyak 4 kejadian demam intrapartum (8,2\%). Walaupun temuannya cukup banyak, analisis statistik tidak menunjukkan hubungan yang signifikan antara demam intrapartum dengan pneumonia neonatus $(p=0,083)$. 


\section{PEMBAHASAN}

\section{Karakteristik Umum Subjek Penelitian}

Ditemukan sebanyak 69 kasus pneumonia neonates atau sekitar $2,78 \%$ dari total 2478 neonatus yang dirawat di RSUP M. Djamil. Berdasarkan data dari penelitian sebelumnya, kejadian pneumonia neonatus berkisar antara 4\%-8\%. Angka kejadian pneumonia neonatus di RSUP M. Djamil memang tidak begitu tinggi, akan tetapi hal tersebut bisa jadi dikarenakan oleh perbedaan gejala yang kurang spesifik antara pneumonia neonatus dengan penyakit lain seperti sepsis, meningitis, dan penyakit membran hialin. ${ }^{4,11}$

Sebanyak 25 neonatus $(50,02 \%)$ yang menjadi sampel dalam penelitian ini memiliki faktor risiko. Hal ini sejalan dengan data pada penelitian sebelumnya,di mana ditemukan lebih dari 50\% neonatus yang pneumonia tidak memiliki faktor risiko. ${ }^{2}$

Pada penelitian ini 93,87\% dari kejadian pneumonia neonatus terjadi pada rentang usia 0-10 hari. Temuan ini tidak jauh berbeda dengan penelitian yang dilakukan di Manado, dengan temuan kejadian pneumonia neonatus sebanyak $95,31 \%$ pada rentang usia 0-7 hari. $^{12}$

Ditinjau dari faktor risiko yang ditemukan, KPD merupakan faktor risiko yang paling banyak, yaitu sebesar 22,4\%. Presentase temuan KPD pada penelitian ini berbeda cukup jauh dengan penelitian sebelumnya yang dilakukan terhadap 228 kasus KPD, hanya sebanyak $7 \%$ neonatus yang mengalami pneumonia. $^{13}$

\section{Hubungan BBLR dengan Pneumonia Neonatus}

Tidak didapatkan hubungan yang signifikan antara BBLR dengan pneumonia neonatus $(p=0,46)$. Hal ini bertentangan dengan penelitian yang telah dilakukan sebelumnya yang menunjukkan bahwa faktor risiko yang paling berpengaruh terhadap pneumonia neonatus adalah BBLR dan kelahiran preterm. Temuan pada penelitian lain tersebut menunjukkan bahwa semakin rendah berat lahir semakin tinggi kemungkinan terjadi pneumonia neonatus. ${ }^{9,10}$

Perbedaan ini mungkin dipengaruhi berbagai faktor yang lain yang tidak diteliti. Menurut beberapa penelitian, infeksi saluran kemih, persalinan memanjang dan kurangnya asuhan antenatal secara signifikan berpengaruh terhadap kejadian pneumonia neonatus. ${ }^{8,14}$

\section{Hubungan Kelahiran Preterm dengan Pneumonia Neonatus}

Hanya ditemukan sebanyak lima (10,2\%) neonatus preterm dari sampel yang ada. Secara statistik, tidak ditemukan hubungan yang signifikan antara kelahiran preterm dengan kejadian pneumonia neonatus $(p=0,372)$. Hal ini bertolak belakang dengan penelitian sebelumnya yang menunjukkan bahwa kejadian pneumonia sangat sering terjadi $(72 \%$ dari total kasus) pada kelahiran preterm. Neonatus yang lahir pada usia 34 minggu diobservasi memiliki risiko pneumonia 7,6 kali lebih besar dibandingkan neonatus yang lahir pada usia 38-39 minggu. ${ }^{15,16}$

Perbedaan yang terjadi mungkin disebabkan karena ketidakakuratan pencatatan usia kehamilan. Tidak semua ibu dari subjek penelitian berkunjung ke dokter untuk asuhan antenatal rutin. Selain itu, hanya ada 15 ibu $(30,6 \%)$ yang melahirkan di RSUP Dr. M. Djamil, sehingga dokter tidak selalu bisa mengkonfirmasi kebenaran usia kehamilan yang disampaikan sang ibu ketika melakukan anamnesis.

\section{Hubungan KPD dengan Pneumonia Neonatus}

Temuan KPD adalah sebanyak 11 (22,4\%) dari total 49 neonatus sampel. Penelitian sebelumnya menyatakan bahwa KPD merupakan faktor yang signifikan terhadap kejadian pneumonia neonatus terutama yang terjadi karena proses intrauterine. Hasil analisis statistik pada penelitian ini tidak menemukan hubungan yang signifikan antara KPD dengan pneumonia neonatus $(p=0,616) .{ }^{17}$

Perbedaan dengan penelitian sebelumnya mungkin disebabkan karena faktor durasi KPD tidak dipertimbangkan dalam penelitian ini. Menurut penelitian lain, terdapat hubungan linear antara kejadian infeksi pada neonatus dengan durasi terjadinya KPD. Pada penelitian tersebut, kejadian tertinggi diobservasi pada KPD dengan durasi $25 \mathrm{jam}$. Menurut literatur lainnya, faktor risiko pneumonia neonatus adalah durasi KPD lebih dari 18 jam. ${ }^{7,14}$ 


\section{Hubungan Demam Intrapartum dengan Pneumonia Neonatus}

Hasil analisis statistik tidak menunjukkan adanya hubungan yang signifikan antara demam intrapartum dengan pneumonia neonatus $(p=0,083)$. Menurut penelitian sebelumnya, terdapat hubungan linear terhadap peningkatan risiko infeksi pada neonatus. Peningkatan risiko infeksi terlihat pada suhu $37,5^{\circ} \mathrm{C}$ sampai $38^{\circ} \mathrm{C}$. Peningkatan ekstrim dari risiko infeksi pada neonatus diobservasi pada suhu lebih dari $38^{\circ} \mathrm{C}$. Pada suhu $39,16^{\circ} \mathrm{C}$ terdapat lonjakan kasus infeksi empat kali lipat dibandingkan dengan suhu $38,3^{\circ} \mathrm{C}$. Penelitian yang telah dilakukan menunjukkan bahwa neonatus yang ibunya mengalami demam intrapartum berisiko mengalami pneumonia $(p<$ $0,001)^{7,8}$

Perbedaan ini mungkin disebabkan karena pada ibu yang tidak melahirkan di RSUP M. Djamil, suhu tubuh ibu tidak secara langsung diukur sehingga riwayat demam dapat dengan mudah disangkal ketika dokter melakukan anamnesis.

\section{KESIMPULAN}

Tidak terdapat hubungan antara BBLR, kelahiran preterm, KPD, dan demam intrapartum dengan kejadian penumonia neonatus di RSUP M. Djamil periode 2010-2012.

\section{DAFTAR PUSTAKA}

1. Stoll BJ, Kliegman RM. The fetus and the neonatal infant. Dalam: Kliegman RM, Bonita, Stanton, Geme J, Schor N, Behrman RE, editor (penyunting). Nelson Textbook of Pediatrics. Edisi ke-19. Philadelphia: Elsevier; 2011. hlm. 519-23, $573,623$.

2. Duke T. Neonatal pneumonia in developing countries. Arch Dis Child Fetal Neonatal. 2005; 90: 211-9.

3. Mandell LA, Wunderink R. Pneumonia. Dalam: Fauci AS, Braunwald E, Kasper DL, Hauser SL, Longo DL, Jameson JL, et al. Harrison's principles of internal medicine. Edisi ke-17. USA: McGrawHill; 2008. hlm. 1619-20.
4. Barnett ED, Klein JO. Bacterial infections of the respiratory tract. Dalam: Remington JS, Klein JO, Baker CJ, Wilson CB, editor (penyunting). Infectious disease of the fetus and newborn infant. Edisi ke-6. Philadelphia: Elsevier; 2006. hlm. 3056, 309.

5. Greenough A. Respiratory disorders in the newborn. Dalam: Chernick V, Boat TF, Wilmott RW, Bush A. Kendig's disorders of the respiratory tract in children. Edisi ke-7. Philadelphia: Elsevier; 2006. hlm. 326-7.

6. Rudan I, Boschi-Pinto C, Biloglav Z, Mulholland K, Campbell H. Epidemiology and etiology of childhood pneumonia. Bulletin of The World Health Organization. 2008;86:408-16.

7. Puopolo KM, Draper D, Wi S, Newman TB, Zupancic J, Leberman E, et al. Estimating the probability of early-onset infection on the basis of maternal risk factors. Pediatrics. 2011;128:115563.

8. Choudhury AM, Nargis S, Mollah AH, Kabir LM, Sarkar RN. Determination of risk factors of neonatal pneumonia. MMJ. 2010;19(3):323-9.

9. Wojkowska-Mach J, Borszewska-Komacka M, Domanska J, Gulczynska E, Helwich E, et al. Early-onset infection of very low birth weight infants in polish neonatal intensive care units. Pediatr Infect Dis J. 2012;31(7): 691-5.

10. Ying YF, Chen SQ, Hu XY, Wang NL, Liu HL, et al. Risk factors for ventilator-associated pneumonia in neonates and the changes of isolated pathogens. CJCP. 2010;12(12):936-9.

11. Black RE, Cousens S, Johnson HL, Lawn JE, Rudan I, Bassani DG, et al. Global, regional, and national causes of child mortality in 2008: a systematic analysis. Lancet. 2010;375:1-25.

12. Jufri J, Wahani A, Wilar R. Profil pneumonia neonatus yang dirawat di RSUP Prof Dr. RD Kandou Manado. ECLINIC. 2013;1(2).

13. Gezer A, Yalciner EP, Guralp O, Yedigoz V, llikkan $\mathrm{B}$, Altinok $\mathrm{T}$, et al. Neonatal morbidity and mortality results in preterm premature rupture of membranes. Turk Arch Ped. 2011;46:287-92. 
14. McGuire W, Clerihew L, Fowlie PW. Infection in the preterm infant. BMJ. 2004;329:1277-80.

15. Gessner BD, Castrodale L, Soriano-Gabarro M. Aetiologies and risk factor for neonatal sepsis and pneumonia mortality among Alaskan infants. Epidemiol. Infect. 2005;133; 877-81.
16. Hibbart JA. Respiratory morbidity in late preterm infants. JAMA. 2010;304(4):419-25.

17. Malinowski L. Premature rupture of membranes one fetus from a multiple pregnancy. Ginekol Pol. $2011 ; 82(10): 775-80$ 